\title{
Black Bear, Ursus americanus, Denning Chronology and Den Site Selection in the Northeastern Cascades of Washington
}

\author{
WiLLIAM L. GAINES \\ U.S. Forest Service, 215 Melody Lane, Wenatchee, Washington 98801 USA
}

Gaines, William L. 2003. Black Bear, Ursus americanus, denning chronology and den site selection in the northeastern Cascades of Washington. Canadian Field-Naturalist 117(4) 626-633.

I studied Black Bear denning chronology and den site selection during 1995-1998 in the northeastern Cascade Mountains of Washington. Male Black Bears entered dens between 22 October and 19 November and emerged between 4 April and 7 May. Females entered dens somewhat sooner, between 15 October and 19 November, and emerged later than males, 4 April and 22 May. These den entry and emergence dates were similar to those reported at similar lattitudes in northwestern Montana. Roads had an important influence on den site selection by Black Bears in this study area. Bears selected dens in areas with no open roads $>200$ ha in size, $>500 \mathrm{~m}$ from the nearest open road, and 1500-2000 $\mathrm{m}$ in elevation. The combination of information on denning chronology and site characterstics should allow managers to coordinate human activities to reduce the potential for disturbance to denning Black Bears.

Key Words: Black Bear, Ursus americanus, northeastern Cascade Mountains, denning chronology, den site characteristics.

Black Bear (Ursus americanus) hibernation has been studied in many areas in North America (Aune 1994; Clark et al. 1998; Hamilton and Marchinton 1980; Hellgren and Vaughan 1989; Oli et al. 1997; Schooley et al. 1994; Smith 1985; Weaver and Pelton 1994; Wooding and Hardisky 1992). Black Bears hibernate in dens throughout their range, but the length of denning and types of dens vary among geographic regions and habitat conditions. In general, bears in southern habitats den for shorter periods than those in northern habitats where winters are longer and more severe (Smith 1985; Hellgren and Vaughan 1989; Weaver and Pelton 1994).

Hibernation in Black Bears is an energy-conserving strategy used to survive winter periods when food is limited and ambient temperatures unfavorable for efficient thermoregulation (Johnson et al. 1978; Johnson and Pelton 1980; Pelton et al. 1980; Johnson and Pelton 1981). The survival value of winter dormancy is particularly evident for Black Bears because their foraging efficiency is closely tied to seasonal plant cycles (Ewer 1973). Bears are believed to remain active prior to denning until a negative energy balance occurs (Schooley et al. 1994). During hibernation, metabolic rates of bears are reduced substantially and they do not normally eat, drink, urinate or defecate (Folk et al. 1972; Nelson et al. 1973; Nelson and Beck 1984). Parturition and early maternal care occurs in dens, and lack of adequate den sites may result in litter loss or complete reproductive failure (Hamilton and Marchinton 1980; Alt 1984; Smith 1985; Weaver and Pelton 1994). Black Bears may be at risk of being killed by predators if dens do not provide adequate protection (Paquet and Carbyn 1986; Ross et al. 1988; Smith and Follman 1993; Boyd and Heger 2000). Human disturbance has been documented to cause den abandonment, which can lead to increased winter weight loss (Tietje and Ruff 1980; Goodrich and Berger 1994). Because of these factors, Black Bears likely select dens that provide energetic efficiency and are relatively safe from predation, human or other disturbances, and weather (Oli et al. 1997).

Understanding the denning ecology of Black Bears and the influence of human activities is important for the proper development of Black Bear management plans and evaluation of the effects of human activities on Black Bear habitat (Pelton 1985; Hillman and Yow 1986; Hellgren and Vaughan 1989; Weaver et al. 1990; Linnell et al. 2000). Claar et al. (1999) and Linnell et al. (2000) identified the need to develop denning habitat models in order to manage human activities to avoid or minimize impacts to denning bears.

Although the denning ecology of Black Bears has been studied extensively in North America, few studies have investigated Black Bear denning in Washington (Poekler and Hartwell 1973; Lindzey and Meslow 1976), and no studies have been conducted on den site selection in the North Cascades of Washington. The objectives of this study were: (1) Describe Black Bear denning chronology, (2) Assess factors that influence Black Bear den site selection, (3) Develop a GIS model of potential denning habitat within the study area, and (4) Provide recommendations on the management of human activities and Black Bear denning.

\section{Study Area}

The Okanogan Study Area was located on the Methow Ranger District, Okanogan National Forest (Figure 1). Bears were captured and radio-collared in both backcountry and front-country areas. Some of the bear locations occurred in areas with limited access and were only accessible by foot. Most of the radio-collared bears are located in areas used for logging and recreational 


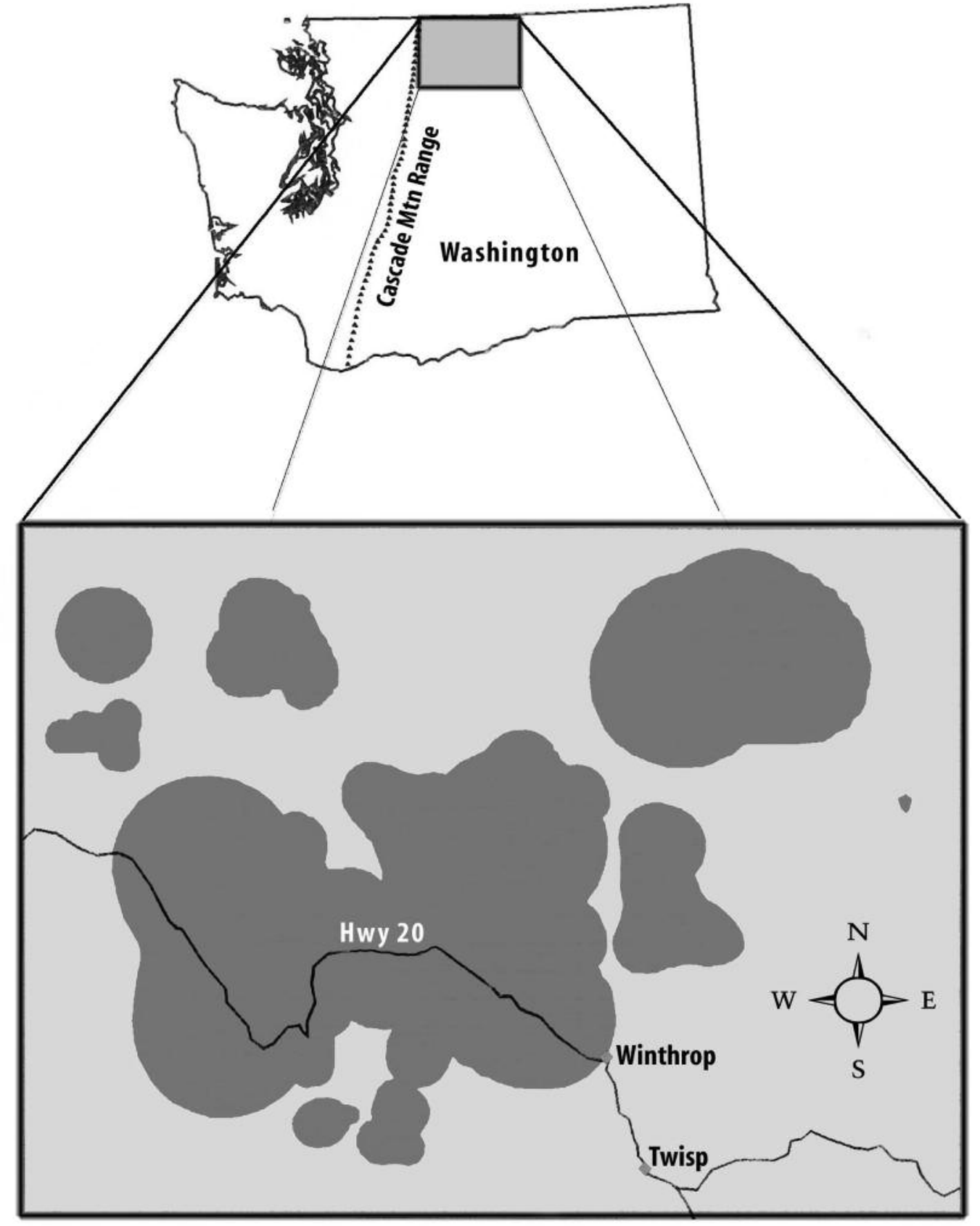

Study Area

Black Bear Home Ranges

- Towns

- Roads

FIGURE 1. The Okanogan Study Area in the northeastern Cascades of Washington. 
activities. Elevations range from about $500 \mathrm{~m}$ in the valley bottoms to $3000 \mathrm{~m}$ near the crest of the Cascade mountains. Precipitation near the Cascade crest averaged about $150-200 \mathrm{~cm} /$ year and precipitation at the lower elevations on the east side of the study area averaged $25-30 \mathrm{~cm} /$ year, falling mostly as snow. Vegetation conditions varied from open Bitterbrush (Purshia tridentata) slopes on the low elevation eastern portion of the study area, to Douglas-fir (Pseudotsuga menziesii) and Ponderosa Pine (Pinus ponderosa) forests at the lower and mid elevations, and montane and alpine vegetation beginning at about $1500 \mathrm{~m}$. Roads are generally distributed along the drainages and along the eastern portion of the study area in the vicinity of human communities. Road densities range from $<1 \mathrm{~km} / \mathrm{km}^{2}$ to a high of $>3 \mathrm{~km} / \mathrm{km}^{2}$.

\section{Methods}

Black Bears were captured in Aldrich snares or darted from a helicopter and fitted with radio-collars and monitored 1-2 times/week using aerial telemetry from 1995 to 1998 (see Koehler et al. 2001 for details). This allowed bears to be tracked to their dens and entry and exit dates to be estimated.

Once bears were assumed to be denned, 2-3 additional telemetry flights were used to verify denning and the den location. Den locations were plotted on 1:24 000 United States Geological Survey quad maps and then digitized into an ARC INFO geographic information system (GIS). The accuracy of the aerial telemetry locations was evaluated with 54 test collars and found to be 180 meters ( \pm 63 meters, $95 \% \mathrm{CI}$ ). Because dens were located using multiple aerial relocations their accuracy is likely higher than the relocations based on single observations. The den locations were probably accurate to within 100 meters.

The vegetation map developed for the North Cascades using Landsat and ground sampling (Gaines et al. 1994) provided the basis for the development of Black Bear habitat maps. These vegetation data were updated to account for fires and timber harvest that have occurred since the original mapping was completed. A list of the vegetation types used in this analysis is shown in Table 1.

Digital terrain data were used to develop elevation zones and aspect categories (Table 1). The study area was divided into five elevation zones: 501-1000 meters, 1001-1500 meters, 1501-2000 meters, 20012500 meters, and $>2500$ meters. The study area was also classified into four aspect categories: North (27145 degrees), East (46 to 135 degrees), South (136-225 degrees), and West (226-270 degrees). The location of each den site was digitized using the GIS to determine the appropriated elevation and aspect category.

The most current roads data layer (as of 1998) available on the Okanogan National Forest was used to assess roads in two ways. First, a moving windows GIS routine with a $1-\mathrm{km}$ radius circular window was used to develop a road density map of the study area. Road densities were divided into the following categories: (1) areas with no open roads $>200$ ha in size, (2) areas with no open roads 40-200 ha in size, (3) areas with no open roads $<40$ ha in size, (4) areas with open road densities from $0.1-1 \mathrm{~km} / \mathrm{km}^{2}$, and (5) areas with open road densities $>1 \mathrm{~km} / \mathrm{km}^{2}$. Second, GIS maps were used to determine the straight-line distance from den sites and 200 random points within the study area to the nearest open road. These distances were recorded as continuous variables and then categorized into: 0-500, 501-1000, 1001-2000, 2001-3000, 3001-4000, 4001-5000, and $>5000$ meters.

All statistical analyses were conducted using PROSTAT (version 1.52) statistical software package. T-tests were used to determine if any statistical differences occurred between male and female den site locations for continuous variables (elevation, distance to roads). For categorical variables (road density zone, aspect, vegetation type), proportions of den sites in each category were arcsine transformed prior to testing for differences between males and females. ChiSquare and Kolmogorov-Smirnov (K-S) goodness of fit tests (Zar 1996) were used to determine if the den site characteristics differed from those available within the study area. K-S tests were used for variables that were recorded on an ordinal scale (Zar 1996) such as road densities, elevations, and distance from roads. The boundary of the study area encompased all of the movements of the radio-collared bears during the study period and was delineated by major ridges and drainages (Alldredge et al. 1998). Analyses were conducted for all den sites, male den sites, and female den sites.

A GIS-based denning habitat model was developed using den site characteristics that were found to be significant when data for bear dens were pooled. This model was used to develop GIS maps of potential denning habitat within the study area. Summary statistics were derived from the potential denning habitat maps.

\section{Results}

Male Black Bears $(n=20)$ entered their dens $(n=21$ entry dates) between 22 October and 19 November (Table 2). Females $(n=9)$ entered dens $(n=20$ entry dates) from 15 October to 19 November (Table 2). For male Black Bears $(n=9)$ emergence dates $(n=16)$ ranged from 4 April to 7 May, and female $(n=7)$ emergence dates $(n=12)$ ranged from 9 April to 22 May (Table 2).

A total of 65 den sites were located between 1995 and 1998, representing den sites used by 29 different Black Bears. Twenty-nine den sites from nine different female Black Bears, and 36 den sites from 20 male bears were used in this analysis.

Males and females denned at similar distances to roads $(t=-0.024, p=0.98)$ and at similar elevations $(\mathrm{t}=-1.103, \mathrm{p}=0.27)$. Female Black Bear dens were located an average of 4339 meters $( \pm 249395 \%$ CI) 
TABLE 1. Den site variables and their availabity, and number of den sites used in the analysis of den site selection by Black Bears on the Okanogan Study Area, 1995-1998.

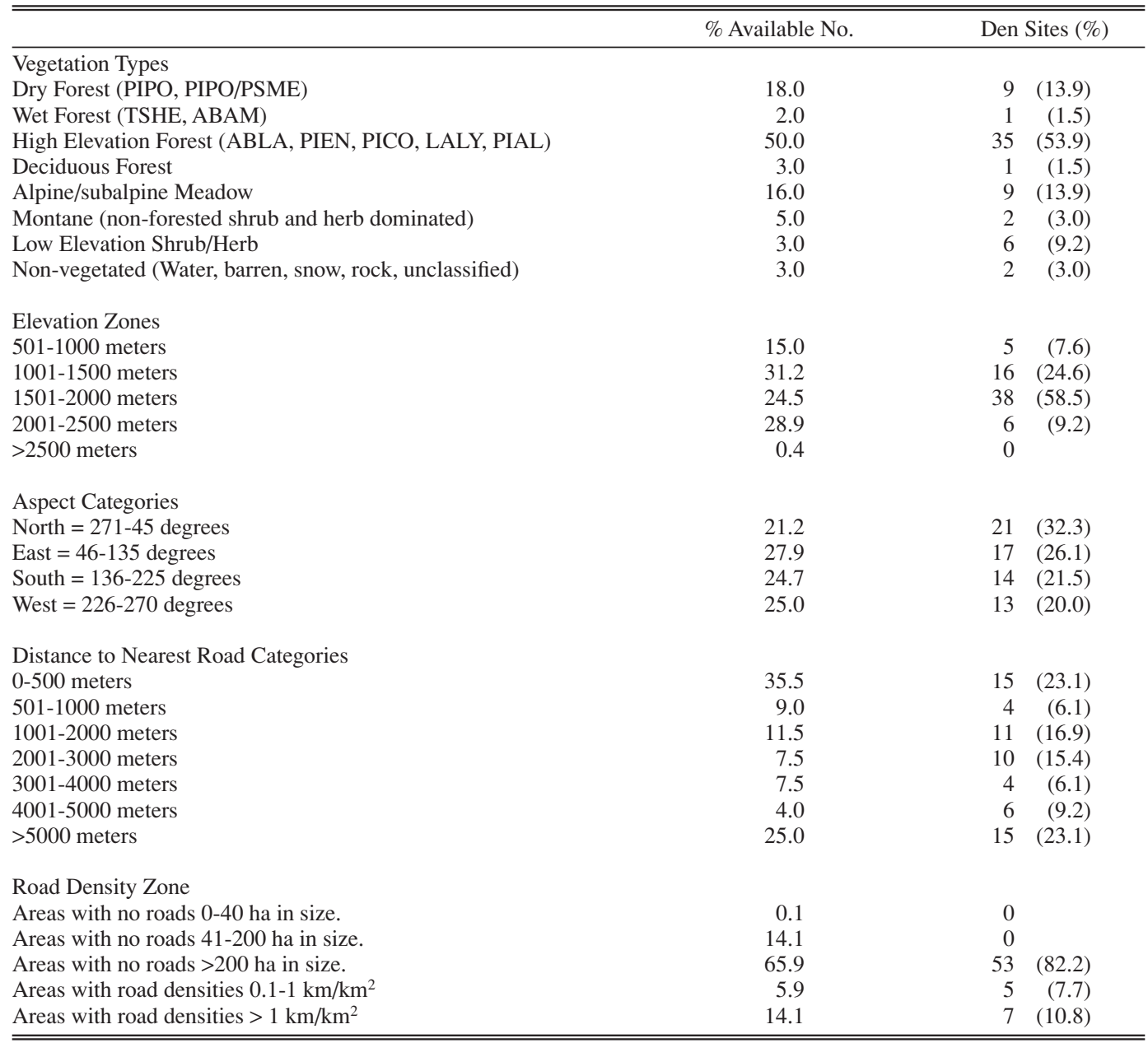

from the nearest roads and at 1550 meters $( \pm 14395 \%$ CI) in elevation. Male den sites were located an average of 4373 meters $( \pm 157995 \% \mathrm{CI})$ from the nearest road and at 1649 meters $( \pm 11895 \% \mathrm{CI})$ in elevation. There were no differences between male and female den site locations for road density zones $(\mathrm{t}=0.025$, $\mathrm{p}=0.810)$, aspect $(\mathrm{t}=0.001, \mathrm{p}=0.999)$, and vegetation type $(\mathrm{t}=0.187, \mathrm{p}=0.857)$. Based on the results of these analyses, no differences were identified between male and female den sites so I pooled den sites for the remainder of the analyses.

When compared to their availability within the study area, several habitat variables were correlated with den site selection. Black Bears used den sites with the following characteristics: areas with no open roads $>200$ ha in size $\left(82 \%\right.$ of the den sites, $\left.d_{\max }=10, \mathrm{p}<0.05\right)$, $>500$ meters from an open road (77\% of the den sites, $\left.d_{\max }=11, \mathrm{p}=0.02\right), 1501-2000$ meters in elevation
( $58 \%$ of the den sites, $\left.d_{\max }=14, \mathrm{p}=0.002\right)$. Aspect (Chi Square $=4.74, \mathrm{p}=0.19$ ) and vegetation (Chi Square $=2.99, \mathrm{p}=0.88$ ) were not used different than expected.

A GIS model of denning habitat within the study area was developed based on the following: areas with no open roads that were $>200$ ha in size, areas that were $>500$ meters from the nearest open road, and areas that were between 1500 to 2000 meters in elevation. These variables were used to produce a map of potential denning habitat using ARC INFO GIS for a large portion of the Okanogan National Forest (Figure 2). Approximately 276015 ha of potential denning habitat were identified, which included about $39 \%$ of the Okanogan National Forest lands west of the Okanogan River. Approximately $61 \%$ of the potential denning habitat is located within designated wilderness areas. 
TABLE 2. A comparison of Black Bear denning entrance and emergence dates from studies conducted in the western United States and southwestern Canada.

\begin{tabular}{|c|c|c|c|c|}
\hline Sex & Entrance Dates & Emergence Dates & Study Area Location & References \\
\hline Male & $\begin{array}{l}2^{\text {nd }} \text { week October } \\
-1^{\text {st }} \text { week November }\end{array}$ & $2^{\text {nd }}-4^{\text {th }}$ week April & NW Montana & Kasworm and Manley 1988 \\
\hline Female & $1^{\text {st }-3^{\text {rd }} \text { week October }}$ & $\begin{array}{l}3^{\text {rd }} \text { week April - } \\
2^{\text {nd }} \text { week May }\end{array}$ & NW Montana & Kasworm and Manley 1988 \\
\hline NA & $\begin{array}{l}9 \text { October - } \\
27 \text { November }\end{array}$ & 11-30 April & West-central Idaho & Amstrup and Beecham 1976 \\
\hline NA & $\begin{array}{l}\text { late October - } \\
\text { early November }\end{array}$ & mid-April - mid-May & N-central Montana & Jonkel and Cowan 1971 \\
\hline NA & $\begin{array}{l}13 \text { October - } \\
30 \text { November }\end{array}$ & 20 March - 5 May & NW Montana & Aune 1994 \\
\hline NA & $\begin{array}{l}\text { mid-November - } \\
\text { early December }\end{array}$ & $\begin{array}{l}\text { early March - } \\
\text { early May }\end{array}$ & $\begin{array}{l}\text { Sierra/Sweetwater } \\
\text { Moutains, California }\end{array}$ & Goodrich and Berger 1994 \\
\hline NA & $\begin{array}{l}\text { end September - } \\
\text { early November }\end{array}$ & $\begin{array}{l}\text { early April - } \\
\text { early May }\end{array}$ & N-central Montana & Mack 1989 \\
\hline NA & mid-October & mid-May & SW British Columbia & Allen 2001 \\
\hline Male & $\begin{array}{l}22 \text { October - } \\
19 \text { November }\end{array}$ & 4 April - 7 May & $\mathrm{N}$-central Washington & This Study \\
\hline Female & $\begin{array}{l}15 \text { October - } \\
19 \text { November }\end{array}$ & 9 April - 22 May & N-central Washington & This Study \\
\hline
\end{tabular}

\section{Discussion}

The den entrance dates from this study appeared to be earlier than those reported for the Sierra and Sweetwater Mountains of California and Nevada (Goodrich and Berger 1994), but were similar to the dates reported from northwestern Montana (Jonkel and Cowan 1971; Kasworm and Manley 1988; Aune 1994), southwestern British Columbia (Allen 2001), and westcentral Idaho (Amstrup and Beecham 1976; Reynolds and Beecham 1980) (Table 2). The den emergence dates for Black Bears from this study were similar to those reported for northwestern Montana (Jonkel and Cowan 1971; Kasworm and Manley 1988; Aune 1994) and west-central Idaho (Amstrup and Beecham 1976; Reynolds and Beecham 1980) (Table 2). Black Bears in the Sierra and Sweetwater mountains of California and Nevada emerged from their dens earlier (Goodrich and Berger 1994) (Table 2).

A variety of factors have been described that appear to influence the denning period of Black Bears. Some researchers suggested that the fall food supply has the most important influence on den entrance (Tietje and Ruff 1980; Beecham et al. 1983; O'Pezio et al. 1983), and others suggested the importance of weather (Lindzey and Meslow 1976). It may be a combination of factors that vary by geographic location which ultimately determine Black Bear denning periods. My observations suggest that fall food supply and the availability of adequate snow cover for insulation are important factors that determine when bears enter dens in north-central Washington. Understanding the den- ning chronology of Black Bears should be useful to managers to coordinate human activities to reduce disturbance to denned bears (Mack 1989; Goodrich and Berger 1994).

Linnell et al. (2000) reviewed the available literature on the characteristics of Black Bear den sites and found that in more mountainous areas 20-50 degree slopes and moderate elevations were generally used. Aspect selection, however, was complex and generally presumed to be influenced by the local stability of snow conditions (Linnell et al. 2000). Research conducted in the western US also reported a wide variety of den site situations. For example Lindzey and Meslow (1976) reported that the percent slope or the aspect did not influence use of den sites by Black Bears on Long Island, Washington. Goodrich and Berger (1994) reported that Black Bears denning in the Sierra Mountains in California selected north to eastfacing aspects and selected slopes over level areas for denning. Mack (1989) and LeCount (1983) reported that most dens in their study areas (north-central Montana and Arizona, respectively) occurred on northerly aspects. However, in the Sweetwater Mountains, California, bears used slopes or aspects for denning equal to their availability (Goodrich and Berger 1994). Slope and aspect were not significant variables in this study either, although more male den sites were located on north slopes than female den sites. Elevation was important to den site use by Black Bears in this study and in the Beartooth Mountains of Montana (Mack 1989). This may be a response by bears to move to the higher 


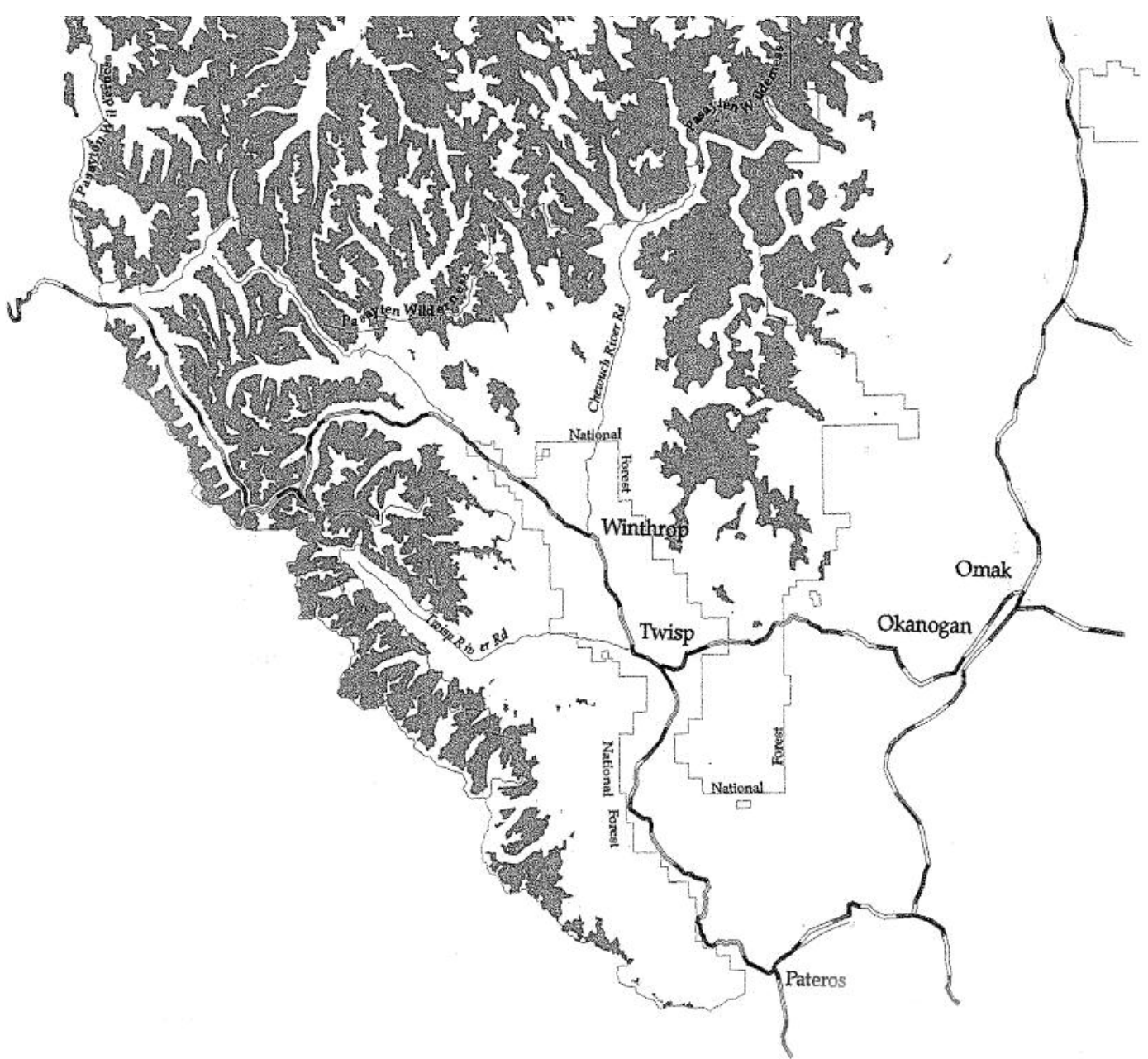

FIGURE 2. The distribution of potential denning habitat (shaded areas) based on the denning habitat model for the Okanogan National Forest, Washington.

elevations prior to denning where snow pack is greater resulting in better insulative qualities (Craighead and Craighead 1972).

Road aspects were correlated with den sites used by bears in this and other study areas. Goodrich and Berger (1994) reported that Black Bears generally denned at distances $\geq 0.8 \mathrm{~km}$ from roads and Tietje and Ruff (1983) reported distances of $\geq 0.3 \mathrm{~km}$. These figures are comparable to the $>0.5 \mathrm{~km}$ from dens to open roads from this study. Several authors have suggested that bears use den sites that are well concealed (Beecham et al. 1983; LeCount 1983) and inaccessible to humans (Novick and Stewart 1982; Goodrich and Berger 1994). This may be an important adaptive strategy to avoid predation (Paquet and Carbyn 1986; Ross et al. 1988; Smith and Follman 1993) and reduce the potential of human disturbance. Several studies have shown that bears may abandon their dens if disturbed by hu- mans (Lindey and Meslow 1976; Hamilton and Marchinton 1980; LeCount 1983; Goodrich and Berger 1994). Den abandonment can have consequences to bears by increasing winter fat loss (Tietje and Ruff 1980) which could influence cub production and survival (Mack 1989). Rogers (1976) showed that if fat reserves drop too low, embryo implantation and fetal development may be halted. More research is needed to understand the physiological consequences of various levels and types of human activities (Linnell et al. 2000).

The potential denning habitat model, in combination with the information about the denning chronology of Black Bears in the study area should provide managers with tools to evaluate the affects of forest management activities on bear denning. In addition, this information could be used by managers to coordinate human activities to reduce the potential for disturbance to bears 
during the denning period. This may be important as human activities have been shown to cause bears to abandon their dens (Goodrich and Berger 1994), and can lead to decreased survival and productivity (Johnson and Pelton 1981).

\section{Acknowledgments}

Funding for this project was provided by the Washington Department of Fish and Wildlife Black Bear Research Project and the U.S. Forest Service. I think Ken Raedeke, John Marzluff, Jim Agee, John Lehmkuhl, and Gary Koehler for their reviews of previous versions of this manuscript. I thank Andrea Gold, Ginger Holser, and Danielle Munzing for their field assistance.

\section{Literature Cited}

Alldredge, J. R., D. L. Thomas, and L. L. McDonald. 1998. Survey and comparison of methods for study of resource selection. Journal of Agricultural, Biological, and Environmental Statistics 3: 237-253.

Allen, M. 2001. [Abstract] Denning ecology of Black Bears in southwest British Columbia. Proceedings of the $7^{\text {th }}$ Western Black Bear Workshop, Coos Bay, Oregon.

Alt, G. L. 1984. Black bear cub mortality due to flooding of natal dens. Journal of Wildlife Management 48: 1432-1434.

Amstrup, S. C., and J. Beecham. 1976. Activity patterns of radio-collared Black Bears in Idaho. Journal of Wildlife Management 40: 340-348.

Aune, K. E. 1994. Comparative ecology of black and grizzly bears on the Rocky Mountain front, Montana. International Conference on Bear Research and Management 9: 365-374

Beecham, J. J., D. G. Reynolds, and M. G. Hornocker. 1983. Black bear denning activities and den characteristics in west-central Idaho. International Conference on Bear Research and Management 5: 79-86.

Boyd, D. K., and E. E. Heger. 2000. Predation of a denned Black Bear, Ursus americanus, by a grizzly bear, Ursus arctos. Canadian Field-Naturalist 114: 507-508.

Claar, J. J., N. Anderson, D. Boyd, M. Cherry, B. Conard, R. Hompesch, S. Miller, G. Ohlson, H. Ihisle Pac, J. Waller, T. Wittinger, and H. Youmans. 1999. Carnivores. Pages 7.10-7.63 in Effects of recreation on Rocky Mountain wildlife: A Review for Montana. Coordinated by G. Joslin and H. Youmans, Committee on Effects of Recreation on Wildlife. Montana Chapter of The Wildlife Society. 307 pages.

Clark, J. D., S. G. Hayes, and J. M. Pledger. 1998. A female Black Bear denning habitat model using a geographic information system. Ursus 10: 181-185.

Craighead, F. C., and J. J. Craighead. 1972. Grizzly bear prehibernation and denning activities as determined by radiotracking. Wildlife Monograph (32). 35 pages.

Ewer, R. F. 1973. The carnivores. Cornell University Press, Ithaca, New York. 494 pages.

Folk, F. E., M. A. Folk, and J. J. Minor. 1972. Physiological condition of three species of bears in winter dens. International Conference on Bear Research and Management 2: 107-124.

Gaines, W. L., R. H. Naney, P. H. Morrison, J. R. Eby, G. F. Wooten, and J. A. Almack. 1994. Use of Landsat multispectral scanner imagery and geographic information systems to map vegetation in the North Cascades ecosystem. International Conference on Bear Research and Management 9: 533-547.

Goodrich, J. M., and J. Berger. 1994. Winter recreation and hibernating Black Bears Ursus americanus. Biological Conservation 6: 105-110.

Hamilton, R. J., and R. L. Marchinton. 1980. Denning activity of Black Bears in the coastal plain of North Carolina. Proceedings of the $4^{\text {th }}$ International Conference on Bear Research and Management, Kalispell, Montana.

Hellgren, E. C., and M. R. Vaughan. 1989. Denning ecology of Black Bears in a southeastern wetland. Journal of Wildlife Management 53: 347-353.

Hillman, L. L., and D. L. Yow. 1986. Timber management for Black Bear. Proceedings of the Eastern Workshop on Black Bear Management and Research 8: 125-136.

Johnson, K. G., D. O. Johnson, and M. R. Pelton. 1978. Simulation of winter heat loss for a Black Bear in a closed tree den. Proceedings of the Eastern Workshop on Black Bear Management and Research 4: 155-166.

Johnson, K. G., and M. R. Pelton. 1980. Environmental relationships and the denning period of Black Bears in Tennessee. Journal of Mammalogy 61: 653-660.

Johnson, K. G., and M. R. Pelton. 1981. Selection and availability of dens for black bears in Tennessee. Journal of Wildlife Management 45: 111-119.

Jonkel, C. J., and I. M. Cowan. 1971. The Black Bear in the spruce-fir forest. Wildlife Monograph (27). 57 pages.

Kasworm, W., and T. Manley. 1988. Grizzly bear and Black Bear ecology in the Cabinet Mountains of northwest Montana. Montana Department of Fish, Wildlife and Parks, Helena, Montana. 122 pages.

Koehler, G. M., P. Briggs Hall, M. H. Norton, and D. J. Pierce. 2001. Implant- versus Collar-transmitter use on Black Bears. Wildlife Society Bulletin 29: 600-605.

LeCount, A. L. 1983. Denning ecology of Black Bears in central Arizona. International Conference on Bear Research and Management 5: 71-78.

Lindzey, F. G., and E. C. Meslow. 1976. Winter dormancy in Black Bears in southwestern Washington. Journal of Wildlife Management 40: 408-415.

Linnell, J. D. C., J. E. Swenson, R. Andersen, and B. Barnes. 2000. How vulnerable are denning bear to disturbance. Wildlife Society Bulletin 28: 400-413.

Mack, J. A. 1989. Black bear dens in the Beartooth Face, south-central Montana. International Conference on Bear Research and Management 8: 273-277.

Nelson, R. A., H. W. Wahner, J. D. Jones, R. D. Ellefson, and P. E. Zollman. 1973. Metabolism of bears before, during and after winter sleep. American Journal of Physiology 224: 491-496.

Nelson, R. A., and T. D. Beck. 1984. Hibernation adaptation in the Black Bear: implication for management. Proceedings of the Eastern Workshop on Black Bear Research and Management 7: 48-53.

Novick, H. J., and G. R. Stewart. 1982. Home range and habitat preferences of black bears in the San Bernadino Mountains of southern California. California Fish and Game 67: 21-35.

Oli, M. K., J. A. Jacobson, and B. D. Leopold. 1997. Denning ecology of Black Bears in the White River National Wildlife Refuge, Arkansas. Journal of Wildlife Management 61: 700-706.

O'Pezio, J., S. H. Clarke, and C. Hackford. 1983. Chronology of Black Bear denning in the Catskill region of 
New York. International Conference on Bear Research and Management 5: 87-94.

Paquet, P. C. and L. N. Carbyn. 1986. Wolves, Canis lupus, killing denning black bears, Ursus americanus, in the Riding Mountain National Park area. Canadian Field-Naturalist 100: 371-372.

Pelton, M. R., L. E. Beeman, and D. C. Eager. 1980. Den selection of Black Bears in the Great Smoky Mountains National Park. International Conference on Bear Research and Management 4: 149-152.

Pelton, M. R. 1985. Habitat needs of Black Bears in the east. Pages 49-53 in Wilderness and natural areas in eastern United States: A management challenge. Edited by D.L. Kulhavy and R. N. Conner. Stephen F. Austin University, Nacogdoches, Texas.

Poekler, R. J., and H. D. Hartwell. 1973. Black bear of Washington: its biology, natural history, and relationship to forest regeneration. Washington State Department of Game, Biology Bulletin (14), Olympia, Washington.

Reynolds, D., and J. J. Beecham. 1980. Home range activities and reproduction of Black Bears in west-central Idaho. International Conference on Bear Research and Management 3: 181-190.

Rogers, L. L. 1976. Effects of mast and berry crop failures on survival, growth, and reproductive success of Black Bears. Transactions of the North American Wildlife and Natural Resources Conference 41: 431-438.

Ross, P. I., G. E. Hornbeck, and B. L. Horejsi. 1988. Late denning Black Bear killed by grizzly bear. Journal of Mammalogy 69: 818-820.
Schooley, R. L., C. R. McLaughlin, G. J. Matula, Jr., and W. B. Krohn. 1994. Denning chronology of female Black Bears: effects of food, weather, and reproduction. Journal of Mammalogy 75: 466-477.

Smith, T. R. 1985. Ecology of Black Bears in the bottomland hardwood forest in Arkansas. Ph.D. thesis, University of Tennessee, Knoxville. 209 pages.

Smith, M. E., and E. H. Follman. 1993. Grizzly bear, Ursus arctos, predation of a denned Black Bear, Ursus americanus. Canadian Field-Naturalist 107: 97-99.

Tietje, W. D., and R. L. Ruff. 1980. Denning behavior of Black Bears in boreal forest in Alberta. Journal of Wildlife Management 44: 858-870.

Weaver, K. M., D. K. Tabberer, L. U. Moore, Jr., G. A. Chandler, J. C. Posey, and M. R. Pelton. 1990. Bottomland hardwood forest management for Black Bears in Louisiana. Proceedings of the Annual Conference of the Southeastern Association of Fish and Wildlife Agencies 44: 342-350.

Weaver, K., and M. R. Pelton. 1994. Denning ecology of Black Bears in the Tensas River Basin of Louisiana. International Conference on Bear Research and Management 9: 427-433.

Wooding, J. D., and T. S. Hardisky. 1992. Black bear denning in northcentral Florida. Journal of Mammalogy 73: 895-898.

Zar, J. H. 1996. Biostatistical Analysis. $3^{\text {rd }}$ Edition. Prentice Hall, Upper Saddle River, New Jersey.

Received 18 December 2002

Accepted 5 April 2004 